\title{
Assessment of Arsenic Toxicity in Spinacia Plant: Physiological Aspect
}

\section{Urvashi Sinha}

\author{
Department of Botany, Patna Women's college, Autonomous \\ Patna University, Patna, Bihar 800001
}

\section{*Corresponding author details: Urvashi Sinha; urvashi.bot@patnawomenscollege.in}

\begin{abstract}
Arsenic (As) is a chemical element which has become environmental toxin now days due its presence in large concentration in water and soil. It remains in the environment for an extensive period. Although it is a non-essential element for plant, the rooted plants absorb Arsenic from the soil. Even a trace amount of Arsenic is enough for affecting the plant growth and development. Test sample Spinacia sp. is a green leafy vegetable that belongs to the family Amaranthaceae. It is distributed all over the world. It is a good source of minerals, vitamins, ascorbic acid, carotenoids, phenols and omega 3fatty acid, therefore, called as the power house of nutrients. Background soil prepared with the Arsenic level $0.013 \mathrm{mg} / \mathrm{kg}$, treated with three different concentrations of Arsenic $0.02 \mathrm{mg} / \mathrm{l}, 0.06 \mathrm{mg} / \mathrm{l}$ and $0.08 \mathrm{mg} / \mathrm{l}$ showed marked changes in the physiology of test sample in the retention period of 30 days. Percent germination was recorded as $16.6 \%$ in the soil containing $0.08 \mathrm{mg} / \mathrm{l}$. Synthesis of chlorophyll a and chlorophyll b was recorded on 5th, 15th and 30th day. It was estimated highest $44.343 \mathrm{mg}$ and 17.837 $\mathrm{mg}$ in the sample plant grown at the lowest concentration of Arsenic $(0.02 \mathrm{mg} / \mathrm{l})$ in the soil. Significantly, this research work addresses the physiological aspect and the results provide scientific understanding of this research area of Arsenic toxicity in soil plant systems.
\end{abstract}

Keywords: Arsenic; Spinacia sp.; UV-Vis Spectrophotometer; Chlorophyll a and Chlorophyll b

\section{INTRODUCTION}

Heavy metals toxicity means excess availability of metals in our environment. Changes in environment due to toxic heavy metals bring about the changes in the physiology of plants, animals and human beings (Shallari et al., 2016). Heavy metals like $\mathrm{As}, \mathrm{Pb}, \mathrm{Cr}, \mathrm{Ni}, \mathrm{Cu}, \mathrm{Cd}$ etc. are very toxic to human beings as well as plants and animal species. It can damage the whole food chain by entering into the plants through the soil particles. It is also known that heavy metals can also destroy the ecological balance of aquatic plants because trace amount of arsenic is present in all water reservoirs (Imran et al., 2013). Heavy metals can not only disturb the plant metabolic activity but can also bring about sudden change in population size and diversity of the soil.

Arsenic is one of the most significant and priority pollutants. Arsenic toxicity is a well-known global health issue. It affects the plant growth, productivity and metabolic activity which results into the death of the plant bodies. Even a trace amount of Arsenic is enough. for affecting the plant growth (Garg et al., 2011). One of the most damaging effects of as in plants is oxidative stress caused by an increase in the production of reactive oxygen species which may alter the normal metabolism of plants and damage cell membranes, causing inhibition of photosynthesis and growth as reported by Miteva et al., (2015).

Spinacia oleracea is a green leafy vegetable that belongs to the family Amaranthaceae. It is distributed all over the world. It is a good source of minerals, vitamins, ascorbic acid, carotenoids, phenols and omega 3 fatty acid (Williams and Long 1997).
Spinacia oleracea is called as the power house of nutrients as it has vitamin C, iron, calcium and minerals. It is termed as super food because of all these nutrients content. It helps in regulating blood pressure, promote eye health and flavonoids present in it function as antioxidant and act as anticancer agent in our body (Miano 2016).

In this study, focus has been on decrease of chlorophyll content in the leaves of Spinacia oleracea. and change in growth and other physiological character that indicates high concentration of Arsenic. As earlier reported, Arsenic limits the plant growth and production (Kumar et al., 2010).

\section{MATERIALS AND METHOD}

The study was carried out in the laboratory of Department of Botany, Patna Women's College Patna. Seeds and pots were purchased from local market of Anishabad, Patna.

\section{EXPERIMENTAL SETUP}

The experiments were done in triplicates. Soil was collected from a local nursery of Patna. The experiments were performed in flower pots of capacity $1 \mathrm{~kg}$. Total 9 pots for the test sample and one pot for control was taken. All the unwanted materials like stones, plastics, grasses, dry roots etc. were removed and after obtaining the good quality of soil it was mixed properly. Before sowing the seeds, $\mathrm{pH}$ value and moisture content of the soil was tested (Kumar et al., 2015). 30 seeds of Spinacia sps. were sown in each pot.

For the treatment of test samples with Arsenic, method of Evangelou et al., (2010) was followed. 
Sodium Arsenate was used as the source of Arsenic. Background soil was prepared with the Arsenic level $0.013 \mathrm{mg} / \mathrm{kg}$. Three different concentrations of Arsenic i.e $0.02 \mathrm{mg} / \mathrm{l}, 0.06 \mathrm{mg} / \mathrm{l}$ and $0.8 \mathrm{mg} / \mathrm{l}$ was prepared in distilled water. One pot was treated with distilled water as control. Each pot was treated regularly with $150 \mathrm{ml}$ of Arsenic solution daily for 30 days. The whole procedure was done in triplicates for the retention period of 30 days.

\section{ESTIMATION OF PHOTOSYNTHETIC PIGMENTS}

Chlorophyll-a and Chlorophyll-b contents in the leaves test sample plant was estimated following the method of Ritchie (2018). 100mg of the fresh leaves of the test sample was grinded with $5 \mathrm{ml}$ of $80 \%$ acetone. For preparation of leaf extract. Optical density of each solution was measured at 663 and $645 \mathrm{~nm}$ against $80 \%$ Acetone blank. Using UVVIS spectrophotometer. The concentration of chlorophyll was calculated by using the formula;
Chlorophyll a $=12.7($ A663) -2.69 (A645)

Chlorophyll $b=22.9$ (A645) - 4.68(A663)

Where,

$\mathrm{A}=$ Absorbance at specific wavelength

At the end of retention period, the concentration of Sodium Arsenate in the soil was estimated from each sample pot by measuring the optical density Length of the seedling and no. of leaves per sample pot was recorded on 30th day. (Jasrotia et al., 2014).

\section{RESULTS AND DISCUSSION}

The result of the study reveals Arsenic toxicity on the physiological aspects through the various scientific experiments performed on the test sample plant of Spinacia. The percentage germination, seedling length, no. of leaves formed and the pigment content decreased considerably as the concentration of Arsenic increased in the soil.

TABLE 1: Percentage germination on 5th day

\begin{tabular}{|c|c|c|c|c|c|}
\hline \multirow{2}{*}{ Sl. No. } & \multirow{2}{*}{$\begin{array}{c}\text { Retention } \\
\text { Period }\end{array}$} & $\begin{array}{c}\text { Sample pots with Different } \\
\text { concentration of arsenic } \\
\text { (mg/l) }\end{array}$ & $\begin{array}{c}\text { No. of seed } \\
\text { shown }\end{array}$ & $\begin{array}{c}\text { No. of seeds } \\
\text { germinated }\end{array}$ & $\begin{array}{c}\text { Mean Percentage } \\
\text { Germination } \\
\text { (\%) }\end{array}$ \\
\hline \multirow{2nnnyy}{*}{5} & Control & 30 & 30 & 100 \\
\hline \multirow{2}{*}{5 days } & 0.2 & 30 & 25 & 83.3 \\
\cline { 3 - 5 } & & 0.6 & 30 & 20 & 66.6 \\
\hline 4 & 0.8 & 30 & 05 & 16.6 \\
\hline
\end{tabular}

TABLE 2: Observational changes on the 30th day

\begin{tabular}{|c|c|c|c|}
\hline Sl. No. & Test samples(mg/l) & $\begin{array}{c}\text { Height of seedling } \\
\text { (cm) }\end{array}$ & $\begin{array}{c}\text { No. of leaves on the seedlings } \\
\text { (mean) }\end{array}$ \\
\hline 1 & Control & $7.3 \mathrm{~cm}$ & 10 \\
\hline 2 & 0.2 & $6.1 \mathrm{~cm}$ & 8 \\
\hline 3 & 0.6 & $4.7 \mathrm{~cm}$ & 5 \\
\hline 4 & 0.8 & $3.5 \mathrm{~cm}$ & 4 \\
\hline
\end{tabular}

TABLE 3: Estimation of chl. a and chl. b using UV-VIS Spectrophotometer

\begin{tabular}{|c|c|c|c|}
\hline Duration & $\begin{array}{c}\text { Plant sample with } \\
\text { different arsenic } \\
\text { conc.(mg/l) }\end{array}$ & $\begin{array}{c}\text { Chlorophyll a } \\
\text { (mg/l) }\end{array}$ & $\begin{array}{c}\text { Chlorophyll b } \\
\text { (mg/l) }\end{array}$ \\
\hline & & Average value & Average value \\
\hline $5^{\text {th }}$ day & Control & 32.469 & 18.822 \\
\hline & 0.2 & 14.594 & 14.089 \\
\hline & 0.6 & 15.139 & 4.574 \\
\hline & 0.8 & 6.147 & 6.936 \\
\hline & & & 17.436 \\
\hline $15^{\text {th }}$ day & Control & 32.944 & 12.233 \\
\hline & 0.2 & 16.8228 & 9.756 \\
\hline & 0.6 & 15.439 & 4.974 \\
\hline & 0.8 & 9.330 & 17.978 \\
\hline $30^{\text {th }}$ day & & & 17.837 \\
\hline & Control & 71.401 & 23.646 \\
\hline & 0.2 & 44.343 & $3 . .265$ \\
\hline
\end{tabular}


TABLE 4: Estimation of Arsenic in the test soil samples on 30th day

\begin{tabular}{|c|c|c|c|c|}
\hline Sl. No. & $\begin{array}{c}\text { Concentration of } \\
\text { Sodium arsenate } \\
(\mathbf{m g} / \mathbf{l})\end{array}$ & $\begin{array}{c}\text { Dry wt. of test } \\
\text { soil }\end{array}$ & $\begin{array}{c}\text { Amount of } \\
\mathbf{N a H C O}_{\mathbf{3}}\end{array}$ & $\begin{array}{c}\text { Concentration of Arsenic } \\
\text { (mean value) } \mathbf{~ m g} / \mathbf{m l}\end{array}$ \\
\hline 1 & 0.2 & $5 \mathrm{~g}$ & $10.5 \mathrm{~g}$ & 0.025 \\
\hline 2 & 0.6 & $5 \mathrm{~g}$ & $10.5 \mathrm{~g}$ & 0.050 \\
\hline 3 & 0.8 & $5 \mathrm{~g}$ & $10.5 \mathrm{~g}$ & 0.004 \\
\hline
\end{tabular}

The given Table 1 shows the germination percentage of the seeds which is lowest in the sample with highest concentration of Arsenic. Similar results have been reported by Imran et al., (2013). The table helps to assess the toxic effect of high level of Arsenic in the soil. Visual assessment was done quantitatively from beginning by observing changes in the leaves no. and its general appearance as shown in Table I. Table 2 shows that the Control have higher growth percent germination rate and growth rate, $7.3 \mathrm{~cm}$ as compare to plant treated with different concentration of arsenic. Study by Bech et al., (1997) has suggest delayed growth and decrease in productivity of the plants under Arsenic stress. In Table 3, Observations on $15^{\text {th }}$ day shows considerable decrease in concentration of Chlorophyll a and b pigments in the test sample plant grown in the highest concentration of Arsenic treated soil. This result was similar to the result reported earlier by Miteva and Merakchiyska (2002). Lowest value of pigment was measured at high Arsenic concentration, $0.8 \mathrm{mg} / \mathrm{l}$. whereas chlorophyll content was estimated highest in the plant of control which had no Arsenic in it. Literature review suggests toxic effect of Arsenic on the physiological process of pigment synthesis (Zhao et al., 2010). In Table 4 different concentrations of Arsenic in the soil after the retention period of 30 days decreased. The results scientifically prooves absorption of Arsenic from the soil by the rooted plant sample.

\section{CONCLUSION}

In this scientific study, different concentration of Arsenic in soil and its effect on the morphological and physiological aspect of the plant Spinacia has been assessed. Arsenic plays a negative role as a growth inhibitor rather than growth promoter. From the present research work by comparing all the different experimental setups with one another it was concluded that plant treated with the high Arsenic concentration $(0.8 \mathrm{mg} / \mathrm{l})$ showed the maximum decrease in the chlorophyll content and its growth was also more affected. On the basis of our observations and statistical analysis of the data, it may be concluded that Arsenic influenced the physiological properties like growth, and pigment synthesis. The study scientifically suggests, inhibition of pigment in the plants may be an indicator of Arsenic in soil and irrigated water.

\section{ACKNOWLEDGEMENT}

I express my great sense of respect and gratitude to the Principal, Dr. Sister M. Rashmi A.C for giving me the opportunity to do this research work at Patna Women's College, Autonomous. Patna,

\section{REFERENCES}

[1] Bech J., Poschenrieder, C. M.Llugany, J. Barcelo (1997) Arsenic and heavy metal contamination of soil and vegetation aroud a copper mine in northern Peru .The Science of the total Environment,203; 83-91.

[2] Evangelou, M. W. Ebel, M. Schaeffer, A (2007). Chelate assisted phytoextraction of heavy metals from soil. Effect, mechanism, toxicity, and fate of chelating agents. Chemosphere, 68, 989-1003. [CrossRef] [PubMed]

[3] Garg N., Singla P. (2011). Arsenic toxicity in crop plants: physiological effects and tolerance mechanisms. Environ ChemLett. 9, 303-32110.1007/s10311-011-0313-7

[4] Imran, MA, Khan RM., Ali Z, Mahmood (2013), T. Toxicity of arsenic (As) on seed germination of sunflower (Helianthus annuus L).Int. J. Phys. Sci. 8, 840-847.

[5] Jasrotia S, Kansal A, Kishore VVN (2014). Arsenic phyco-remediation by cladophora $s p$. Algae and measurement of arsenic speciation and location of active absorption site using electron microscopy. Microchemical 114: 197-202.

[6] Karn SK. (2015). Arsenic (As) contamination: a major risk factor in Xinjiang Uyghur autonomous region of China. Environnmental Pollution 207: 434-435.

[7] Kumar S. Dubey,R.S.; Tripathi,R.D.; Chakrabarty,D.; Trivedi, P.K Omics(2015) Biotechnology of Arsenic stress and detoxification in plants: Current updates and prospective. Environ. Int., 74,221-230

[8] Miano TF (2016); Nutritional value of Spinacia oleraecea spinach-an overview.IntJLifeSciRev. 2(1274: doi: 10.13040/IJPSR.09758232.IJLSR.2(12).172-74.

[9] Miteva, E. Merakchiyska M., (2002). Response of chloroplasts and photosynthetic mechanism of bean plants to excess arsenic in soil. Bulg. J. Agric. Sci. 8, 151-156.

[10] Shallari S, Schwartz C, Hasko A, Morel JL (2016). Heavy metals in soils and plants of serpentine and industrial sites of Albania. Sci Total Environ.;19209: 133-142.

[11] Ritchie R.J: (2018). Consistent sets of spectrophotomertic chlorophyll equation for acetone, methanol and ethanol solvents, photosynth. Res., 89, 27-41.

[12] Williams, Sue Rodwell; Long,Sara(1997).Nutrition and diet therapy.p.229.ISBN 978-081519273-2

[13] Zhao FJ, McGrath SP, Meharg AA (2010). Arsenic as a food chain contaminant: mechanisms of plant uptake and metabolism and mitigation strategies. Annu Rev plant Biol; 61:535 